\section{Energetics of Chloride Secretion in Canine Tracheal Epithelium \\ Comparison of the Metabolic Cost \\ of Chloride Transport \\ with the Metabolic Cost of Sodium Transport}

Michael J. Welṣh

With the technical assistance of Phil Karp

Pulmonary Division and Laboratory of Epithelial Transport, Department of Internal Medicine, University of Iowa College of Medicine, Iowa City, Iowa 52242

compare the metabolic cost of $\mathrm{Cl}$ transport with the metabolic cost of $\mathrm{Na}$ transport.

Several features of ion transport by tracheal epithelium allow this comparison. First, and most important, the energy source for both $\mathrm{Na}$ and $\mathrm{Cl}$ transport is Na-K-ATPase. In Na absorption, $\mathrm{Na}$ enters the cell passively through an amiloride-sensitive apical membrane $\mathrm{Na}$ conductance $(1,2)$. $\mathrm{Na}$ then exits against its electrochemical gradient via the activity of the basolateral $\mathrm{Na}$ $\mathrm{K}$-ATPase $(3,4)$. In $\mathrm{Cl}$ secretion, $\mathrm{Cl}$ enters the cell across the basolateral membrane against its electrochemical gradient by virtue of its coupling to $\mathrm{Na}(3-5)$. $\mathrm{Cl}$ then exits passively across a Cl-conductive apical membrane $(2,5,6)$. The $\mathrm{Na}$ that enters with $\mathrm{Cl}$ is recycled back across the basolateral membrane by the Na-K-ATPase (7). Thus, the Na-K-ATPase provides the energy for $\mathrm{Cl}$ secretion by maintaining a low intracellular $\mathrm{Na}$ concentration.'

The second feature of tracheal epithelium important for this study is that both $\mathrm{Na}$ and $\mathrm{Cl}$ transport are electrogenic (8), so that ion transport rates can be measured as the short-circuit current, Isc, ${ }^{2}$ simultaneously with $\mathrm{O}_{2}$ consumption rate. Third, the rates of $\mathrm{Na}$ absorption and $\mathrm{Cl}$ secretion can be independently changed by a variety of transport inhibitors and secretagogues $(1,9)$.

The purpose of this study was to examine the energetics of $\mathrm{Cl}$ secretion in canine tracheal epithelium by comparing the oxygen consumption required for $\mathrm{Cl}$ transport with the oxygen consumption required for $\mathrm{Na}$ transport. I reasoned that: $(a)$ the metabolic cost of $\mathrm{Na}$ and $\mathrm{Cl}$ transport would be equal if $\mathrm{Cl}$ entry at the basolateral membrane is tightly coupled to $\mathrm{Na}$ entry with a one- to-one stoichiometry, and there are no backleak pathways for $\mathrm{Cl}$ at the basolateral membrane; $(b)$ the metabolic

1. The Na-K-ATPase also indirectly supplies the energy for $\mathrm{Cl}$ secretion by maintaining a negative intracellular voltage. The negative electrical potential difference across both apical and basolateral membranes results from the $\mathrm{K}$ concentration gradient across the $\mathrm{K}$ conductive basolateral membrane $(15,27,29)$.

2. Abbreviations used in this paper: Isc, short-circuit current; $\mathrm{QO}_{2}$, oxygen consumption rate; $\mu \mathrm{eq} / \mu \mathrm{M} \mathrm{O}_{2}$, ratio of microequivalents of ions transported per micromolar $\mathrm{O}_{2}$ consumed. 
cost of $\mathrm{Cl}$ transport would be greater than the cost of $\mathrm{Na}$ transport, if there are leak paths for $\mathrm{Cl}$ exit at the basolateral membrane or the stoichiometry of $\mathrm{Cl}$ entry involve more than one $\mathrm{Na}$ per $\mathrm{Cl}$; or $(c)$ the oxygen cost of $\mathrm{Cl}$ transport would be less than that for $\mathrm{Na}$ if the stoichiometry of the entry step involves more than one $\mathrm{Cl}$ per $\mathrm{Na}$. The results suggest the third possibility.

\section{Methods}

Tissues and solutions. Tracheal epithelium was prepared as previously described (10). Mongrel dogs (25-40 kg) of either sex were anesthetized with pentobarbital $(25 \mathrm{mg} / \mathrm{kg}$ i.v. $)$ and the trachea was removed. We used the poterior membranous portion after removing the muscular layer.

The bathing solution contained (in millimolar): $118.9, \mathrm{NaCl} ; 20.4$, $\mathrm{NaHCO}_{3} ; 2.4, \mathrm{~K}_{2} \mathrm{HPO}_{4} ; 0.6, \mathrm{KH}_{2} \mathrm{PO}_{4} ; 1.2, \mathrm{CaCl}_{2} ; 1.2, \mathrm{MgCl}_{2}$; and 10 , glucose. For $\mathrm{Cl}$-free solutions, $\mathrm{Na}$ gluconate was substituted for $\mathrm{NaCl}$ $\mathrm{CaSO}_{4}$ for $\mathrm{CaCl}_{2}$, and $\mathrm{MgSO}_{4}$ for $\mathrm{MgCl}_{2}$. For Na-free solutions, tetramethylammonium $\mathrm{Cl}$ was substituted for $\mathrm{NaCl}$ and choline $\mathrm{HCO}_{3}$ for $\mathrm{NaHCO}_{3}$. Na concentrations were measured with a flame photometer (Instrumentation Laboratory, Inc., Boston, MA). $\mathrm{Cl}$ concentrations were measured with a chloridometer (Laboratory Glass and Instruments Corp., New York). Chemicals used were: epinephrine (Elkins-Sinn, Inc., Cherry Hill, NJ); bumetanide (a generous gift of Hoffman-LaRoche Inc., Nutley, NJ); amiloride (a generous gift of Merck Sharp \& Dohme Research Laboratories, West Point, PA); ouabain and indomethacin (Sigma Chemical Co., St. Louis, MO). Gentamycin sulfate $(50 \mu \mathrm{g} / \mathrm{ml})$ was present in all solutions.

Measurement of oxygen consumption. The epithelium was mounted between two halves of a lucite chamber (Jim's Instruments Mfg. Inc., Coralville, IA) with a $1.5-\mathrm{cm}^{2}$ aperture. The volume of each bathing solution was $3.4 \mathrm{ml}$. The chamber was water-jacketed to maintain the solution at $37^{\circ} \mathrm{C}$. Magnetic stir bars vigorously stirred both bathing solutions. Chemicals were injected through air-tight ports with a syringe (Hamilton Co., Reno, NV). When oxygen consumption was not being measured, both solutions were bubbled with $95 \% \mathrm{O}_{2}$ and $5 \% \mathrm{CO}_{2}(\mathrm{pH}$ 7.4 at $37^{\circ} \mathrm{C}$ ). Ringers' bridges were used to measure the transepithelial electrical potential difference and to pass current. $\mathrm{Na}$-free and $\mathrm{Cl}$-free agar bridges were prepared by substitution of tetramethylammonium for $\mathrm{Na}$ and gluconate for $\mathrm{Cl}$. All studies were performed under shortcircuit conditions.

To measure oxygen consumption $\left(\mathrm{QO}_{2}\right)$, the bubbling was stopped and Clark-type oxygen electrodes (model 53, Yellow Springs Instrument Co., Inc., Yellow Springs, $\mathrm{OH}$ ) were inserted into each bathing solution. The percent $\mathrm{O}_{2}$ saturation of each bathing solution was continuously measured and recorded on a strip chart recorder. The oxygen electrodes were routinely calibrated in solutions equilibrated with room air and $95 \% \mathrm{O}_{2}$, and occasionally with 51 and $75.6 \% \mathrm{O}_{2}$. The rate of oxygen consumption was calculated from the change in percent saturation of each solution, the solubility of oxygen in Ringers' solution at $37^{\circ} \mathrm{C}$, and the barometric pressure. In preliminary studies, we found that $\mathrm{QO}_{2}$ was stable for periods as long as $3 \frac{1}{2} \mathrm{~h}$, if the rate of transport was stable. Furthermore, $\mathrm{QO}_{2}$ and Isc were stable during repeated measurements (removing and reinserting the $\mathrm{O}_{2}$ electrode) and at $\mathrm{O}_{2}$ saturations from 95 to $30 \%$. During the usual experiment the $\mathrm{O}_{2}$ saturation fell to $\sim 50$ $60 \%$ by the end of the measurement period. We did not go $<30 \% \mathrm{O}_{2}$ saturation. The rate of $\mathrm{O}_{2}$ consumption in the mucosal solution was usually two to four times greater than that in the submucosal solution. The process of measuring $\mathrm{QO}_{2}$ did not change solution temperature (as measured with a microthermistor, Bailey Instruments Co., Inc., Saddle Brook, NJ). $\mathrm{pH}$ (as measured with a miniature $\mathrm{pH}$ electrode, W-P Instruments, Inc., New Haven, CT) did not fall < 7.2. Injection of Ringer's solution or drug vehicle did not change $\mathrm{QO}_{2}$. Lactic acid was measured in the bathing solution by enzymatic analysis (Sigma Chemical Co.).

Results are presented as means \pm SEM. Statistical significance was evaluated by using a paired- $t$ test; a $P$ value $<0.05$ was considered statistically significant.

\section{Results}

Fig. 1 shows the time course of the simultaneous measurement of Isc and $\mathrm{QO}_{2}$ in one representative tissue. This figure also illustrates the protocol that we used for the first series of experiments. Indomethacin $\left(10^{-6} \mathrm{M}\right)$ was added to the mucosal bathing solution for at least $60 \mathrm{~min}$ before the start of the experiment. Indomethacin decreases endogenous prostaglandin production and decreases intracellular cyclic AMP levels, thereby minimizing the rate of $\mathrm{Cl}$ secretion without interfering with the subsequent response to secretagogues $(6,9,11)$. Thus, the Isc in the first part of the figure primarily results from $\mathrm{Na}$ absorption. After measuring a steady state Isc and $\mathrm{QO}_{2}$, we added amiloride $\left(10^{-4} \mathrm{M}\right)$ to the mucosal solution to inhibit $\mathrm{Na}$ transport $(1,2)$. Amiloride decreased both the Isc and the $\mathrm{QO}_{2}$. The decrease in $\mathrm{QO}_{2}$ was attributed to a decrease in the $\mathrm{O}_{2}$ required for $\mathrm{Na}$ transport. After Isc and $\mathrm{QO}_{2}$ stabilized, epinephrine $\left(10^{-6} \mathrm{M}\right.$, mucosal solution) was added to stimulate $\mathrm{Cl}$ secretion $(6,12)$. The magnitude of the change in Isc $\mathrm{QO}_{2}$ was used to calculate the rate of $\mathrm{Cl}$ transport and the rate of $\mathrm{Cl}$ transport-related $\mathrm{O}_{2}$ consumption.

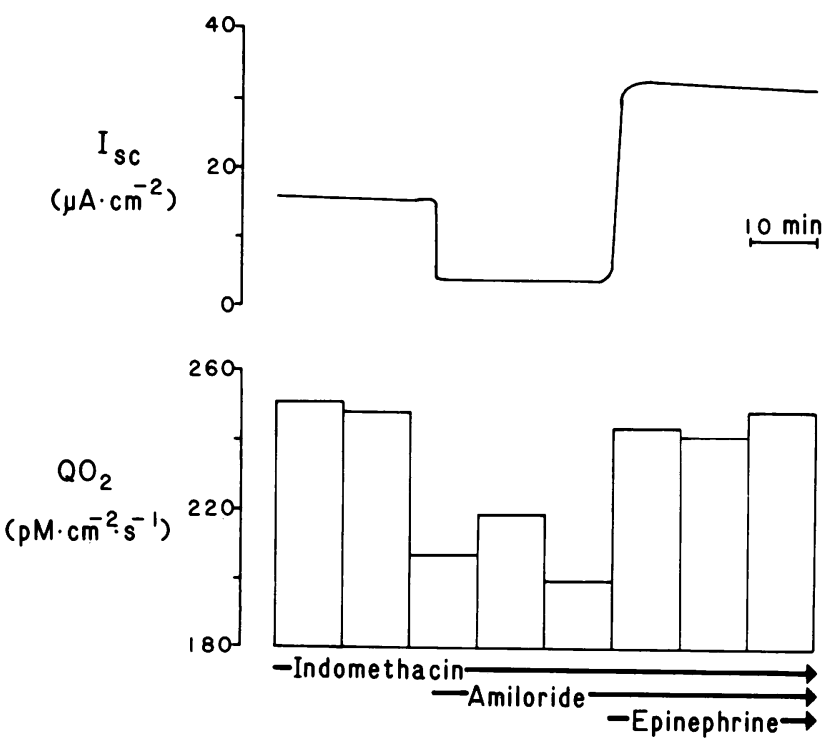

Figure 1. Effect of amiloride $\left(10^{-4} \mathrm{M}\right.$, mucosal solution) and epinephrine $\left(10^{-6} \mathrm{M}\right.$, submucosal solution) on short-circuit current and oxygen consumption. Values are from one representative tissue. Indomethacin $\left(10^{-6} \mathrm{M}\right.$, mucosal solution) was present throughout. 
The magnitude of the changes in Isc and $\mathrm{QO}_{2}$ resulting from the sequential inhibition of $\mathrm{Na}$ transport and then stimulation of $\mathrm{Cl}$ secretion, suggest that the oxygen consumption required for $\mathrm{Cl}$ transport may be less than that for $\mathrm{Na}$ transport. That is, for a similar change in $\mathrm{QO}_{2}$, there is a greater change in the rate of $\mathrm{Cl}$ transport than $\mathrm{Na}$ transport. This point is made more clearly by the data shown in Table I, which gives the values for eight epithelia treated in the same manner as the tissue in Fig. 1. For each individual tissue we calculated a value for the microequivalents of $\mathrm{Na}$ transported per micromolar $\mathrm{O}_{2}$ consumed, from the amiloride-induced changes, and a value for the microequivalents of $\mathrm{Cl}$ transported per micromolar $\mathrm{O}_{2}$ consumed, from the epinephrine-induced changes. Furthermore, we could directly compare these two values for each individual tissue as shown in Fig. 2: For a given $\mathrm{O}_{2}$ consumption, a greater quantity of $\mathrm{Cl}$ than $\mathrm{Na}$ was transported. The mean ratio of $\mathrm{Cl}$ to $\mathrm{Na}$ transported was $2.0 \pm 0.3 \mu \mathrm{eq} \mathrm{Cl} / \mu \mathrm{eq} \mathrm{Na}$, a ratio significantly different from one.

In the analysis of this data, I assume that the experimental interventions did not alter the rate of $\mathrm{O}_{2}$ consumption unrelated to ion transport; i.e., the change in $\mathrm{QO}_{2}$ was entirely attributed to the change in transport. One way of indirectly examining this assumption was to use other agents to change the rate of ion transport. Table II shows the results obtained when amiloride was used to inhibit $\mathrm{Na}$ transport and submucosal bumetanide was used to inhibit $\mathrm{Cl}$ transport. Bumetanide and other loop

Table I. Oxygen Cost of Na and Cl Transport Determined from the Effect of Amiloride and Epinephrine

\begin{tabular}{lrll}
\hline & Isc & \multicolumn{1}{c}{$\mathrm{QO}_{2}$} & $\mu \mathrm{eq} / \mu \mathrm{M} \mathrm{O}_{2}$ \\
\hline & $\mu \mathrm{A} \cdot \mathrm{cm}^{-2}$ & $p m o l \cdot \mathrm{cm}^{-2} \cdot \mathrm{s}^{-1}$ & \\
& & & \\
$\mathrm{Na}$ transport & $34 \pm 4$ & $256 \pm 19$ & \\
$\quad$ Indomethacin $\left(10^{-6} \mathrm{M}\right)$ & $13 \pm 3$ & $220 \pm 19$ & \\
+ Amiloride $\left(10^{-4} \mathrm{M}\right)$ & $-21 \pm 3$ & $-37 \pm 5$ & $6.7 \pm 1.3$ \\
$\Delta$ & & & \\
$\mathrm{Cl}$ transport & & & \\
Indomethacin $\left(10^{-6} \mathrm{M}\right)$ and & $13 \pm 2$ & $226 \pm 20$ & \\
$\quad$ Amiloride $\left(10^{-4} \mathrm{M}\right)$ & $104 \pm 17$ & $313 \pm 29$ & \\
+ Epinephrine $\left(10^{-6} \mathrm{M}\right)$ & $+92 \pm 16$ & $+87 \pm 15$ & $11.5 \pm 1.5$ \\
$\Delta \quad$ & & \\
$\quad\left(\frac{\mu \mathrm{eq} \mathrm{Cl}}{\mu \mathrm{M} \mathrm{O} \mathrm{O}_{2}}\right) \div\left(\frac{\mu \mathrm{eq} \mathrm{Na}}{\mu \mathrm{M} \mathrm{O} \mathrm{O}_{2}}\right)=2.0 \pm 0.3^{*} \frac{\mu \mathrm{eq} \mathrm{Cl}}{\mu \mathrm{eq} \mathrm{Na}}$ & \\
& &
\end{tabular}

Values are mean \pm SEM from eight tissues. Mean ratio of microequivalents of ions transported per micromolar $\mathrm{O}_{2}$ consumed $(\mu \mathrm{eq} / \mu \mathrm{M}$ $\mathrm{O}_{2}$ ) and ratio of microequivalents of $\mathrm{Cl}$ transported to microequivalents of $\mathrm{Na}$ transported per micromolar $\mathrm{O}_{2}$ consumed, were obtained from values calculated for each individual tissue. $\Delta$ represents the difference between the two measurement periods.

* Value significantly different from $1, P<0.05$.

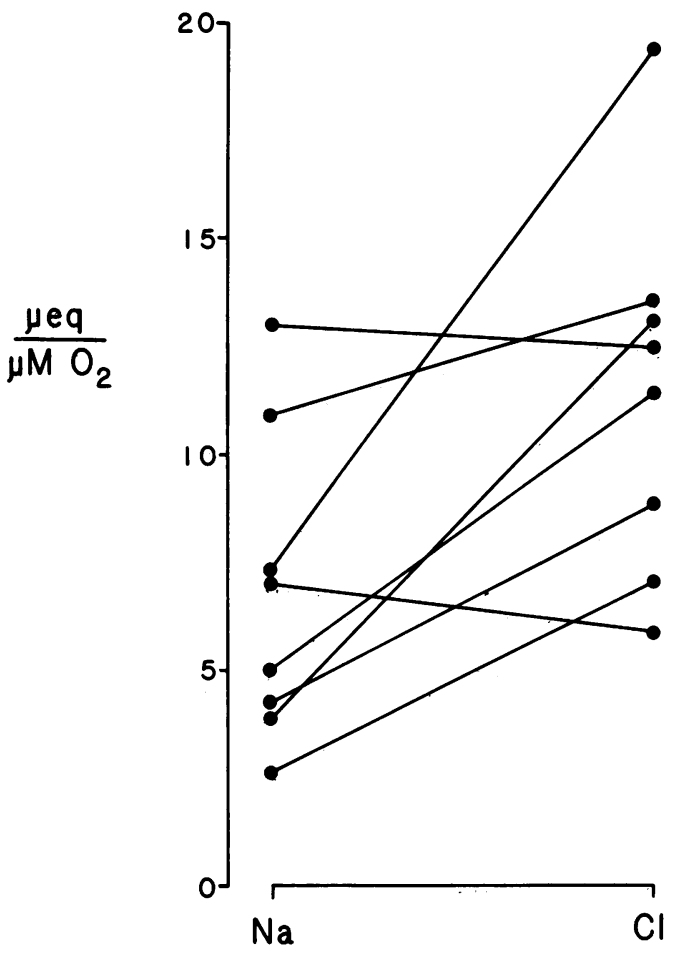

Figure 2. Comparison of the oxygen cost of $\mathrm{Na}$ and $\mathrm{Cl}$ transport $(\mu \mathrm{eq} / \mu \mathrm{M} \mathrm{O})_{2}$ ). The $\mathrm{O}_{2}$ cost of $\mathrm{Na}$ transport was determined from the change in Isc and $\mathrm{QO}_{2}$ induced by amiloride $\left(10^{-4} \mathrm{M}\right)$. The $\mathrm{O}_{2}$ cost of $\mathrm{Cl}$ transport was determined from the change in Isc and $\mathrm{QO}_{2}$ induced by epinephrine. Indomethacin $\left(10^{-6} \mathrm{M}\right)$ was present throughout.

diuretics inhibit $\mathrm{Cl}$ secretion by inhibiting the electrically neutral, $\mathrm{Na}$-dependent $\mathrm{Cl}$ entry step at the basolateral membrane (5, $13,14)$. For these studies the tissues were first incubated with indomethacin, to minimize $\mathrm{Cl}$ secretion, and the change in Isc and $\mathrm{QO}_{2}$ produced by amiloride was used to evaluate $\mathrm{Na}$ transport. After this, submucosal epinephrine was added to stimulate $\mathrm{Cl}$ secretion. Then we measured the change in Isc and $\mathrm{QO}_{2}$ produced by submucosal bumetanide $\left(10^{-4} \mathrm{M}\right)$, to evaluate $\mathrm{Cl}$ transport. Fig. 3 shows that in all six tissues the $\mathrm{O}_{2}$ cost for $\mathrm{Cl}$ transport was less than that for $\mathrm{Na}$ transport. The ratio of $\mathrm{Cl}$ to $\mathrm{Na}$ transport for a given $\mathrm{QO}_{2}$ was significantly greater than one, again suggesting that $\mathrm{Cl}$ transport is energetically more efficient.

The energy for both $\mathrm{Na}$ and $\mathrm{Cl}$ transport is derived from the Na-K-ATPase in tracheal epithelium. Therefore, we also examined the energetics of $\mathrm{Na}$ and $\mathrm{Cl}$ transport by directly inhibiting the Na pump with ouabain $\left(10^{-4} \mathrm{M}\right.$, submucosal solution) $(3,4)$. For each experiment, three tissues from the same dog were studied. One tissue was used to evaluate $\mathrm{Na}$ transport; indomethacin $\left(10^{-6} \mathrm{M}\right.$, mucosal solution) and bumetanide $\left(10^{-4} \mathrm{M}\right.$, submucosal solution) inhibited $\mathrm{Cl}$ transport. One tissue was used to evaluate $\mathrm{Cl}$ transport; amiloride $\left(10^{-4}\right.$ 
Table II. Oxygen Cost of $\mathrm{Na}$ and $\mathrm{Cl}$ Transport Determined from the Effect of Amiloride and Bumetanide

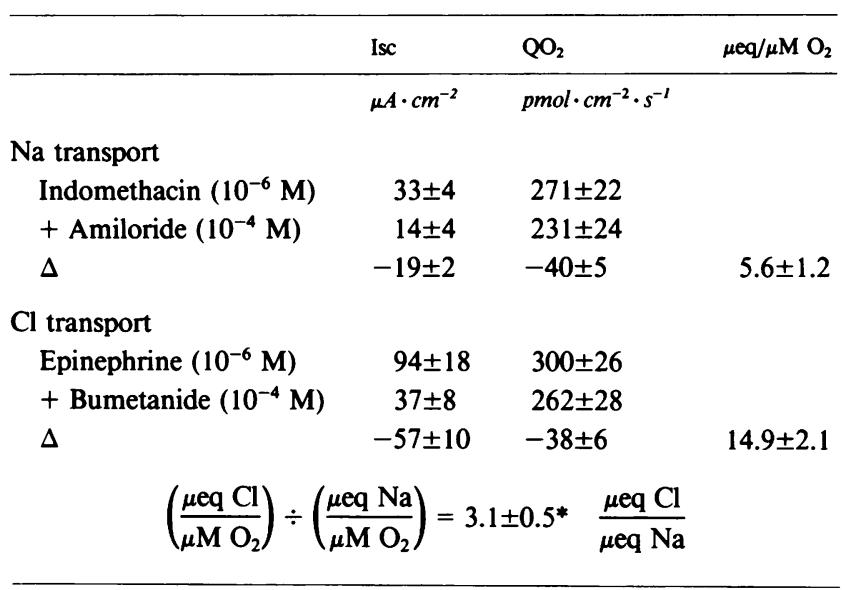

Values are mean \pm SEM from six tissues. During measurement of $\mathrm{O}_{2}$ cost of $\mathrm{Cl}$ transport, indomethacin and amiloride were present in the mucosal solution. See legend of Table I.

* Value significantly different from one, $P<0.05$.

$\mathrm{M}$, mucosal solution) inhibited $\mathrm{Na}$ transport and epinephrine $\left(10^{-6} \mathrm{M}\right.$, submucosal solution) stimulated $\mathrm{Cl}$ secretion. A third tissue was used to evaluate the effect of ouabain on Isc and

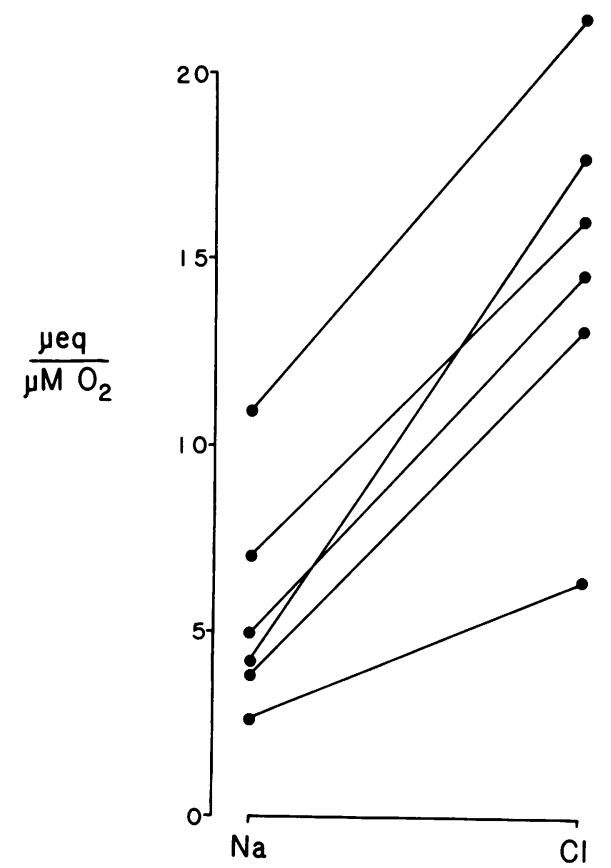

Figure 3. Comparison of the oxygen cost of $\mathrm{Na}$ and $\mathrm{Cl}$ transport. The $\mathrm{O}_{2}$ cost of $\mathrm{Na}$ transport was determined from the change in Isc and $\mathrm{QO}_{2}$ induced by amiloride. The $\mathrm{O}_{2}$ cost of $\mathrm{Cl}$ transport was determined from the change produced by bumetanide $\left(10^{-4} \mathrm{M}\right.$, submucosal solution). Indomethacin was present throughout.
$\mathrm{QO}_{2}$ when transport rates were minimal; amiloride, indomethacin, and bumetanide inhibited both $\mathrm{Na}$ and $\mathrm{Cl}$ transport. The changes in this third tissue will be referred to as "residual." Isc and $\mathrm{QO}_{2}$ were measured during a base-line period and then 20 min after addition of ouabain. The order of studying the three tissues was randomized.

The results are shown in Table III. Ouabain decreased Isc and $\mathrm{QO}_{2}$ in both the $\mathrm{Cl}$-transporting and the Na-transporting tissues and the ratio of $\mathrm{Cl}$ to $\mathrm{Na}$ transport per micromolar $\mathrm{QO}_{2}$ was significantly greater than one. However, despite the presence of both $\mathrm{Na}$ and $\mathrm{Cl}$ transport inhibitors, there was a residual Isc in the third group of tissues. This residual Isc probably represents incomplete inhibition of both $\mathrm{Na}$ and $\mathrm{Cl}$ transport $(1,2,11)$. Ouabain decreased the residual Isc to zero and decreased $\mathbf{Q O}_{2}$. Because of this effect, we subtracted the residual change in Isc and $\mathrm{QO}_{2}$ from the other two tissues in each experiment and recalculated the ratio of the oxygen cost of $\mathrm{Cl}$ vs. $\mathrm{Na}$ transport. The corrected values showed more variability (larger standard errors) but the mean ratio was still significantly different from one.

One final way of comparing the $\mathrm{O}_{2}$ cost of $\mathrm{Na}$ and $\mathrm{Cl}$ transport was to replace $\mathrm{Na}$ and $\mathrm{Cl}$ in the bathing solutions. For this study, epinephrine was present throughout to stimulate $\mathrm{Cl}$ secretion. Isc and $\mathrm{QO}_{2}$ were measured during five separate periods: a "base-line" period ( $\mathrm{NaCl}$ Ringers'); a period with a Na-free mucosal solution; a base-line period; a period with both solutions

Table III. Oxygen Cost of $\mathrm{Na}$ and $\mathrm{Cl}$ Transport Determined from the Effect of Ouabain

\begin{tabular}{llll}
\hline & Na transport & Cl transport & Residual \\
\hline$\Delta \mathrm{Isc}\left(\mu \mathrm{A} \cdot \mathrm{cm}^{-2}\right)$ & $-34 \pm 6$ & $-81 \pm 14$ & $-8 \pm 1$ \\
$\Delta \mathrm{QO}_{2}\left(\mathrm{mmol} \cdot \mathrm{cm}^{-2} \cdot \mathrm{s}^{-1}\right)$ & $-70 \pm 16$ & $-69 \pm 12$ & $-19 \pm 10$ \\
$\mu \mathrm{eq} / \mu \mathrm{M} \mathrm{O}_{2}$ & $6.0 \pm 1.1$ & $15.2 \pm 4.4$ & $7.9 \pm 7.1$ \\
$\mu \mathrm{eq} / \mu \mathrm{M} \mathrm{O}_{2}$ (corrected) & $6.8 \pm 2.1$ & $20.3 \pm 4.2$ & \\
$\left(\frac{\mu \mathrm{eq} \mathrm{Cl}}{\mu \mathrm{M} \mathrm{O}_{2}}\right) \div\left(\frac{\mu \mathrm{eq} \mathrm{Na}}{\mu \mathrm{M} \mathrm{O}}\right)$ & $=2.6 \pm 0.5^{*}$ & $\frac{\mu \mathrm{eq} \mathrm{Cl}}{\mu \mathrm{eq} \mathrm{Na}}$ & \\
$\left(\frac{\mu \mathrm{eq} \mathrm{Cl}}{\mu \mathrm{M} \mathrm{O}_{2}}\right) \div\left(\frac{\mu \mathrm{eq} \mathrm{Na}}{\mu \mathrm{M} \mathrm{O}_{2}}\right)$ & $($ corrected $)=4.1 \pm 1.1^{*} \frac{\mu \mathrm{eq} \mathrm{Cl}}{\mu \mathrm{eq} \mathrm{Na}}$
\end{tabular}

$\Delta \mathrm{Isc}$ is the change in short-circuit current and $\Delta \mathrm{QO}_{2}$ is the change in $\mathrm{O}_{2}$ consumption rate produced by addition of ouabain $\left(10^{-4} \mathrm{M}\right.$, submucosal solution). Six groups of three tissues were studied. In each group one tissue was treated with indomethacin $\left(10^{-6} \mathrm{M}\right)$ and bumetanide $\left(10^{-4} \mathrm{M}\right)$, "Na transport;" one tissue received epinephrine $\left(10^{-6} \mathrm{M}\right)$ and amiloride $\left(10^{-4} \mathrm{M}\right)$, "Cl transport;" one tissue received indomethacin, bumetanide, and amiloride, "Residual." The $\mathrm{QO}_{2}$ after addition of ouabain was $320 \pm 45,304 \pm 32$, and $345 \pm 59$ $\mathrm{pmol} \cdot \mathrm{cm}^{-2} \cdot \mathrm{s}^{-1}$ for the three groups, respectively. Because ouabain inhibited a small Isc and produced a small change in $\mathrm{QO}_{2}$ in the "Residual" tissue, the $\mathrm{O}_{2}$ cost of ion transport $\left(\mu \mathrm{eq} / \mu \mathrm{M} \mathrm{O}_{2}\right)$ and the ratio of $\mathrm{Cl}$ to $\mathrm{Na}$ transported per $\mu \mathrm{M} \mathrm{O}_{2}(\mu \mathrm{eq} \mathrm{Cl} / \mu \mathrm{eq} \mathrm{Na})$ were also "corrected" for the residual changes.

* Value significantly different from one, $P<0.05$. 
Cl-free; and a final base-line period. Between periods, the $\mathrm{O}_{2}$ probes were removed from the chamber; the solutions were changed; and then the $\mathrm{O}_{2}$ probes were reinserted. The order of the two ion substitutions was randomized. At the end of the measurement period the $\mathrm{Na}$ concentration in the $\mathrm{Na}$-free solution was $2.95 \pm 0.40 \mathrm{mM}$ and the $\mathrm{Cl}$ concentration in the $\mathrm{Cl}$ free solution was $0.44 \pm 0.07 \mathrm{mM}$. Unilateral mucosal $\mathrm{Na}$ substitution will not only inhibit $\mathrm{Na}$ absorption, but may also generate a small diffusion voltage across the epithelium $(10,15)$. However, a diffusion voltage will be offset to some extent by a junction voltage of the opposite polarity between the tetramethylammonium-Cl bridges and the $\mathrm{NaCl}$ submucosal solution. Thus, the absolute value of Isc with a Na-free mucosal solution may be subject to a small error.

Table IV shows the results of this study. Due to variability in the individual values, the mean value of microequivalents of $\mathrm{Cl} /$ microequivalents $\mathrm{Na}$ was not statistically different from one $(P=0.08$, by paired analysis). However, in each of the five experiments the ratio of microequivalents of $\mathrm{Cl} / \mathrm{micromolar} \mathrm{O}_{2}$ was greater than the microequivalents of $\mathrm{Na} / \mathrm{micromolar} \mathrm{O}_{2}$. Thus, these results support the conclusion that the metabolic cost of $\mathrm{Cl}$ transport is less than that for $\mathrm{Na}$.

To further test the assumption that the maneuvers used to change $\mathrm{Cl}$ transport rate do not alter cellular energy metabolism other than that responsible for ion transport, we examined the effect of epinephrine and bumetanide in tissues treated with ouabain. Fig. 4 shows that $\mathrm{QO}_{2}$ was not altered by these agents when active transport was inhibited.

To determine if there was any difference in lactate production between $\mathrm{Na}$ - and $\mathrm{Cl}$-transporting tissues, we measured the lactate

Table IV. Oxygen Cost of $\mathrm{Na}$ and $\mathrm{Cl}$ Transport Determined from the Effect of Ion Substitutions

\begin{tabular}{|c|c|c|c|c|}
\hline & Isc & $\mathrm{QO}_{2}$ & & $\mu \mathrm{eq} / \mu \mathrm{M} \mathrm{O}_{2}$ \\
\hline & $\mu \mathrm{A} \cdot \mathrm{cm}^{-2}$ & $\mathrm{pmol} \cdot \mathrm{cm}^{-2} \cdot \mathrm{s}^{-1}$ & & \\
\hline \multicolumn{5}{|l|}{$\mathrm{Na}$} \\
\hline Base line & $84 \pm 10$ & $322 \pm 26$ & & \\
\hline $\mathrm{Na}$-free & $70 \pm 10$ & $296 \pm 32$ & & \\
\hline$\Delta$ & $-14 \pm 2$ & $-26 \pm 8$ & & $8.6 \pm 3.1$ \\
\hline \multicolumn{5}{|l|}{$\mathrm{Cl}$} \\
\hline Base line & $89 \pm 14$ & $279 \pm 22$ & & \\
\hline Cl-free & $21 \pm 3$ & $248 \pm 24$ & & \\
\hline \multirow[t]{2}{*}{$\Delta$} & $-68 \pm 12$ & $-31 \pm 9$ & & $26.3 \pm 4.7$ \\
\hline & $\left(\frac{\mu \mathrm{eq} \mathrm{Cl}}{\mu \mathrm{M} \mathrm{O}_{2}}\right) \div\left(\frac{\mu \mathrm{eq} \mathrm{Na}}{\mu \mathrm{M} \mathrm{O}_{2}}\right)$ & $=5.4 \pm 1.9$ & $\frac{\mu \mathrm{eq} \mathrm{Cl}}{\mu \mathrm{eq} \mathrm{Na}}$ & \\
\hline
\end{tabular}

Values are mean \pm SEM from five tissues. In "Na-free" condition, tetramethylammonium was substituted for $\mathrm{Na}$ in the mucosal solution. In "Cl-free" condition, gluconate was substituted for $\mathrm{Cl}$ in both bathing solutions. Epinephrine $\left(10^{-6} \mathrm{M}\right)$ was present throughout. See legend of Table $I$.

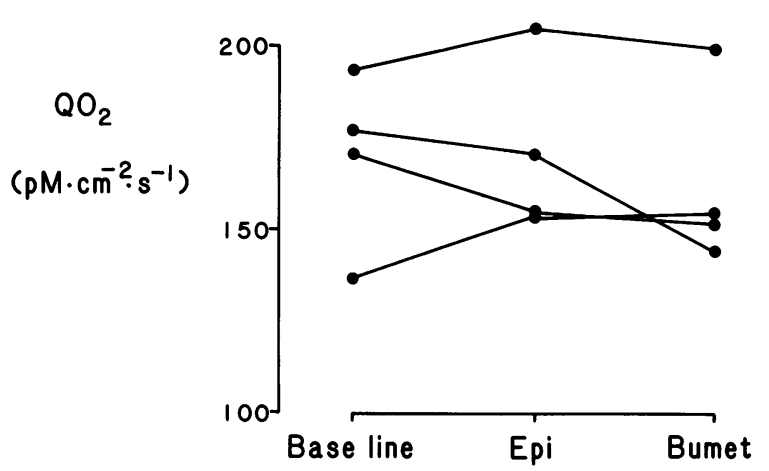

Figure 4. Effect of epinephrine (Epi) and bumetanide (Bumet) on oxygen consumption in ouabain-treated tissues. Ouabain $\left(10^{-4} \mathrm{M}\right.$, submucosal solution) was present throughout. Oxygen consumption was measured during a base-line period, then after addition of epinephrine, and finally after addition of bumetanide.

in the bathing solution at the beginning and end of a 1-h period. The lactate produced by Na-transporting tissues (indomethacin treated) was $44 \pm 30 \mu \mathrm{M} / \mathrm{h}(\mathrm{n}=6)$. Addition of amiloride and epinephrine, to inhibit $\mathrm{Na}$ transport and stimulate $\mathrm{Cl}$ transport, did not significantly change the rate of lactate production $(73 \pm 42$ $\mu \mathrm{M} / \mathrm{h})(P=0.23$ by paired analysis $)$.

\section{Discussion}

The results of this study show that in canine tracheal epithelium, under short-circuit conditions, $\mathrm{Cl}$ secretion is energetically more efficient than $\mathrm{Na}$ absorption. We simultaneously measured the rate of oxygen consumption and the rate of ion transport under a variety of experimental interventions that were designed to alter either $\mathrm{Na}$ or $\mathrm{Cl}$ transport. The data indicate that for one mole of oxygen consumption, the epithelium transports more $\mathrm{Cl}$ ions than $\mathrm{Na}$ ions.

There are only a few previous studies of the energetics of $\mathrm{Cl}$ transport. In isolated perfused shark rectal gland, Silva et al. (16) measured the $\mathrm{O}_{2}$ consumption rate and the rate of $\mathrm{NaCl}$ secretion. Since $\mathrm{Cl}$ secretion is the active transport process (17), they used the rate of $\mathrm{Cl}$ efflux from the gland duct and the total rate of $\mathrm{O}_{2}$ consumption (determined from the arterial-venous $\mathrm{O}_{2}$ difference) to calculate the microequivalents of $\mathrm{Cl} /$ micromolar $\mathrm{O}_{2}$ ratio. On the basis of the predicted number of ATP moles produced per $\mathrm{O}_{2}$ used, and the assumed number of $\mathrm{Na}$ transported per ATP hydrolyzed by the Na pump, they concluded that the gland transported $70 \%$ more $\mathrm{Cl}$ than predicted if $1 \mathrm{~mol}$ of $\mathrm{Cl}$ were transported for every mole of $\mathrm{Na}$ transported by the Na pump. Oxygen consumption has also been measured in frog cornea, another $\mathrm{Cl}$-secreting epithelium. Reinach et al. (18) measured $\mathrm{O}_{2}$ consumption and Zadunaisky et al. (19) measured the rate of $\mathrm{CO}_{2}$ production from radiolabeled glucose. However, the tissues were not mounted as epithelial sheets, so that the rate of metabolism could not be directly correlated 
with the rate of ion transport. Martin and Diamond (20) studied the energetics of $\mathrm{Cl}$ absorption in rabbit gallbladder and found a good correlation between $\mathrm{QO}_{2}$ and isotonic fluid absorption. On the basis of the observed stoichiometry of $\mathrm{Na}$ and $\mathrm{Cl}$ transported per $\mathrm{O}_{2}$ consumed, they concluded that the total number of ions transported ( $\mathrm{Na}$ plus $\mathrm{Cl}$ ), was twice as great as in epithelia that only transport $\mathrm{Na}$ actively, while the stoichiometry of $\mathrm{Cl}$ transport or $\mathrm{Na}$ transport per $\mathrm{O}_{2}$ was similar to that found in Na-transporting epithelia.

It is appropriate to consider the assumptions involved in the present study. First, I assume that the experimental interventions do not change the ratio of $\mathrm{O}_{2}$ consumption to ATP production. The lack of any change in lactate production rate at least suggests that there are not large changes in anaerobic ATP generation. Second, I assume that the various interventions do not change the magnitude of nontransport-related metabolism or ATP utilization. In support of this assumption, neither epinephrine nor bumetanide altered $\mathrm{QO}_{2}$ in tissues in which all ion transport was inhibited with ouabain. Third, I assume that the various interventions do not change the number of $\mathrm{Na}$ ions transported per mole of ATP consumed by the Na-K-ATPase. In support of this assumption, previous studies suggest a constant ratio of $\mathrm{Na}$ transported per $\mathrm{O}_{2}$ consumed within an individual tissue $(21,22)$. Furthermore, in support of all three assumptions, we used four different experimental maneuvers to change $\mathrm{Cl}$ transport and three different experimental maneuvers to alter $\mathrm{Na}$ transport. In all the protocols, the results consistently show that the $\mathrm{O}_{2}$ consumption used for $\mathrm{Cl}$ transport is less than for $\mathrm{Na}$ transport, thereby providing an indirect test of these assumptions.

One of the advantages of this study, in comparison to previous studies, is that our conclusions do not depend upon assumptions about the actual stoichiometry of the metabolic steps between $\mathrm{O}_{2}$ consumption and Na-pump activity; we only assume that the stoichiometry does not change. ${ }^{3} \mathrm{We}$ directly compared the rate of $\mathrm{O}_{2}$ consumption required for $\mathrm{Cl}$ transport to the $\mathrm{QO}_{2}$ required for $\mathrm{Na}$ transport. We were able to do this because the metabolic energy for both transport processes is derived from the Na-K-ATPase. Another advantage of this study is that the ratio of microequivalents of $\mathrm{Cl} /$ microequivalents of $\mathrm{Na}$ transported per micromolar $\mathrm{O}_{2}$ consumed was calculated for each individual tissue. The ability to analyze the data in this way avoids the problems and uncertainties inherent in analysis of averages obtained from a population of epithelia $(21,23)$.

The most straightforward interpretation of this data is that the $\mathrm{Na}$-dependent $\mathrm{Cl}$ entry step at the basolateral membrane

3. In some Na-transporting epithelia the mean ratio of microequivalents of $\mathrm{Na}$ transported per micromotor $\mathrm{O}_{2}$ consumed was $\sim 18$, although substantial variability in the ratio has also been observed. The ratio of 18 is larger than the ratio found in this study; I do not know the reason for this difference. However, as indicated above, the conclusions and validity of this study do not depend upon the absolute value of the stoichiometry between ion transport and oxygen consumption. couples the entry of more than one $\mathrm{Cl}$ to each $\mathrm{Na}$. This interpretation explains the observation that two to three (significantly more than one) $\mathrm{Cl}$ are transported for the same metabolic cost as one $\mathrm{Na}^{4}{ }^{4}$ The mechanism that mediates $\mathrm{Cl}$ entry may represent the cotransport of one $\mathrm{Na}$-one $\mathrm{K}$-two $\mathrm{Cl}$ as has been described in a number of cells including Ehrlich ascites tumor cells (24) and the cortical thick ascending limb of the loop of Henle (25). Several observations would support such a mechanism. First, the $\mathrm{Cl}$ entry step is electrically neutral (6), as would be predicted by this mechanism. Second, loop diuretics inhibit $\mathrm{Cl}$ entry in trachea with a half-maximal dose similar to that required to inhibit the one Na-one $\mathrm{K}$-two $\mathrm{Cl}$ cotransport system $(5,13,14)$. Third, neither removal of $\mathrm{HCO}_{3}$ from the bathing solutions, application of substituted stilbenes (4-acetamido-4'-isothiocyano2,2'-stilbene disulfonate, SITS, or 4,4'-diisothiocyanostilbene2,2'-disulfonate, DIDS), nor addition of acetazolamide was able inhibit $\mathrm{Cl}$ secretion (unpublished observations). These maneuvers would be expected to inhibit neutral $\mathrm{Cl}$ transport via parallel $\mathrm{Cl}-\mathrm{HCO}_{3}$ and $\mathrm{Na}-\mathrm{H}$ cotransport processes. Finally, in shark rectal gland, another $\mathrm{Cl}$-secreting epithelium, studies of the $\mathrm{Cl}$ entry step using basolateral membrane vesicles are consistent with coupled entry of $\mathrm{Na}, \mathrm{K}$, and $2 \mathrm{Cl}(26)$.

Certainly the energy in the $\mathrm{Na}$ gradient is sufficient to drive the entry of more than one $\mathrm{Cl}$ for each $\mathrm{Na}$ transported. Under secreting short-circuit conditions, the electrochemical gradient for $\mathrm{Cl}$ is $-22 \mathrm{mV} \mathrm{(5)} \mathrm{and} \mathrm{the} \mathrm{electrochemical} \mathrm{gradient} \mathrm{for} \mathrm{K}$ is $-24 \mathrm{mV}$ (27). Thus, if the entry step involved the cotransport of one Na-one K-two $\mathrm{Cl}, 68 \mathrm{mV}$ would be required from the $\mathrm{Na}$ electrochemical potential difference. An estimate of the $\mathrm{Na}$ electrochemical gradient from the basolateral membrane voltage $(55-60 \mathrm{mV})$ and the intracellular $\mathrm{Na}$ concentration of $20 \mathrm{mM}$ measured in isolated canine tracheal epithelial cells (28) yields a value of $+107 \mathrm{mV}$, more than sufficient to energize the entry of two $\mathrm{Cl}$ and one $\mathrm{K}$.

The electrochemical potential difference for $\mathrm{Na}$ is used to energize "secondary-active" $\mathrm{Cl}$ transport in a wide variety of both secretory and absorptive epithelia. Thus, these results may be of significance for epithelia other than trachea by suggesting that $\mathrm{Cl}$ transport is coupled to $\mathrm{Na}$ transport in a way that maximizes the use of the metabolic energy used to generate the $\mathrm{Na}$ gradient.

4. We observed some variability in the mean ratio of microequivalents of $\mathrm{Cl} /$ microequivalents of $\mathrm{Na}$ transported per micromolar $\mathrm{O}_{2}$ consumed with the different experimental protocols (Tables I-IV). This variability may have resulted from small discrepancies between the measured changes in Isc and the changes in the $\mathrm{Na}$ and $\mathrm{Cl}$ transport rates. Another possible explanation for the variability is that some of the maneuvers may have had a small and variable effect on nontransport metabolism. Despite this variability, the important point is that the ratio of microequivalents of $\mathrm{Cl}$ per microequivalents of $\mathrm{Na}$ was significantly greater than a ratio of one with all the different maneuvers. In addition, the mean values of microequivalents of $\mathrm{Cl}$ per microequivalents of $\mathrm{Na}$ obtained with the different protocols were not significantly different from one another. 


\section{Acknowledgments}

I thank Drs. John B. Stokes, Russell F. Husted, and Victor Schuster for helpful discussions. The secretarial assistance of Mrs. D. Ollendick, Ms. M. Uhl, and Mrs. A. Aschoff, is gratefully appreciated.

This work was supported by a Program Project Grant (HL-14388) and a research grant (HL-29851) from the National Institutes of Health.

\section{References}

1. Widdicombe, J. H., and M. J. Welsh. 1980. Ion transport by dog tracheal epithelium. Fed. Proc. 39:3062-3066.

2. Welsh, M. J., P. L. Smith, and R. A. Frizzell. 1983. Chloride secretion by canine tracheal epithelium: III. Membrane resistances and electromotive forces. J. Membr. Biol. 71:209-218.

3. Al-Bazzaz, F. J., and Q. Al-Awqati. 1979. Interaction between sodium and chloride transport in canine tracheal mucosa. J. Appl. Physiol. 46:111-119.

4. Widdicombe, J. H., I. F. Ueki, I. Bruderman, and J. A. Nadel. 1979. The effects of sodium substitution and ouabain on ion transport by dog tracheal epithelium. Am. Rev. Respir. Dis. 120:385-392.

5. Welsh, M. J. 1983. Intracellular chloride activities in canine tracheal epithelium. Direct evidence for sodium-coupled intracellular chloride accumulation in a chloride secreting epithelium. J. Clin. Invest. 71:13921401.

6. Welsh, M. J., P. L. Smith, and R. A. Frizzell. 1982. Chloride secretion by canine tracheal epithelium. II. The cellular electrical potential profile. J. Membr. Biol. 70:227-238.

7. Widdicombe, J. H., C. B. Basbaum, and J. Y. Yee. 1979. Localization of Na pumps in the tracheal epithelium of the dog. J. Cell Biol. 82:380-390.

8. Olver, R. E., B. Davis, M. G. Marin, and J. A. Nadel. 1975. Active transport of $\mathrm{Na}^{+}$and $\mathrm{Cl}^{-}$across the canine tracheal epithelium in vitro. Am. Rev. Respir. Dis. 112:811-815.

9. Smith, P. L., M. J. Welsh, J. S. Stoff, and R. A. Frizzell. 1982. Chloride secretion by canine tracheal epithelium. I. Role of intracellular cAMP levels. J. Membr. Biol. 70:217-226.

10. Welsh, M. J., and J. H. Widdicombe. 1980. Pathways of ion movement in the canine tracheal epithelium. Am. J. Physiol. 239:F215F221.

11. Al-Bazzaz, F., V. P. Yadava, and C. Westenfelder. 1981. Modification of $\mathrm{Na}$ and $\mathrm{Cl}$ transport in canine tracheal mucosa by prostaglandins. Am. J. Physiol. 240(9):F101-F105.

12. Al-Bazzaz, F. J., and E. Cheng. 1979. Effect of catecholamines on ion transport in dog tracheal epithelium. J. Appl. Physiol. 47(2):397403.
13. Welsh, M. J. 1983. Inhibition of chloride secretion by furosemide in canine tracheal epithelium. J. Membr. Biol. 71:219-226.

14. Widdicombe, J. H., I. T. Nathanson, and E. Highland. 1983. Effects of "loop" diuretics on ion transport by dog tracheal epithelium. Am. J. Physiol. 245:C388-C396.

15. Welsh, M. J. 1983. Evidence for a basolateral membrane potassium conductance in canine tracheal epithelium. Am. J. Physiol. 244:C377-C384.

16. Silva, P., J. S. Stoff, R. J. Solomon, R. Rosa, A. Stevens, and J. Epstein. 1980. Oxygen cost of chloride transport in perfused rectal gland of Squalus acanthias. J. Membr. Biol. 53:215-221.

17. Silva, P., J. Stoff, M. Field, L. Fine, J. N. Forrest, and F. H. Epstein. 1977. Mechanism of active chloride secretion by shark rectal gland: role of Na-K-ATPase in chloride transport. Am. J. Physiol. 233(4):F298-F306.

18. Reinach, P. S., H. F. Schoen, and O. A. Candia. 1977. Effects of inhibitors of $\mathrm{Na}$ and $\mathrm{Cl}$ transport on oxygen consumption in the bullfrog cornea. Exp. Eye Res. 24:493-500.

19. Zadunaisky, J. A., M. A. Lande, and J. Hafner. 1971. Further studies on chloride transport in the frog cornea. Am. J. Physiol. 221(6):1832-1836.

20. Martin, D. W., and J. M. Diamond. 1966. Energetics of coupled active transport of sodium and chloride. J. Gen. Physiol. 50:295-315.

21. Beauwens, R., and Q. Al-Awqati. 1976. Further studies on coupling between sodium transport and respiration in toad urinary bladder. Am. J. Physiol. 231(1):222-227.

22. Vieira, F. L., S. R. Caplan, and A. Essig. 1972. Energetics of sodium transport in frog skin. I. Oxygen consumption in the shortcircuited state. J. Gen. Physiol. 59:60-76.

23. Al-Awqati, Q., R. Beauwens, and A. Leaf. 1975. Coupling of sodium transport to respiration in the toad bladder. J. Membr. Biol. 22:91-105.

24. Geck, P., C. Peitrzyk, B. C. Burckhardt, B. Pfeiffer, and E. Heinz. 1980. Electrically silent cotransport of $\mathrm{Na}^{+}, \mathrm{K}^{+}$, and $\mathrm{Cl}^{-}$in ehrlich cells. Biochim. Biophys. Acta. 600:432-447.

25. Greger, R., and E. Schlatter. 1981. Presence of luminal $\mathrm{K}^{+}$, a prerequisite for active $\mathrm{NaCl}$ transport in the cortical thick ascending limb of Henle's loop of rabbit kidney. Pflugers Arch. 392:92-94.

26. Hannafin, J., E. Kinne-Saffran, D. Friedman, and R. Kinne. 1983. Ion fluxes and furosemide binding in rectal gland plasma membrane vesicles; evidence for the presence of a $\mathrm{Na}, \mathrm{K}, \mathrm{Cl}$ cotransport system. Kidney Int. 23:257.

27. Welsh, M. J. 1983. Intracellular potassium activities in canine tracheal epithelium. Am. J. Physiol. 245:C248-C254.

28. Widdicombe, J. H., C. B. Basbaum, and E. Highland. 1981. Ion contents and other properties of isolated cells from dog tracheal epithelium. Am. J. Physiol. 241:C184-C192. 